\title{
Kavalactones and Benzoic Acid Derivatives from Leaves of Piper fuligineum Kunth (Piperaceae)
}

\author{
Bruna F. Mazzeu, ${ }^{a}$ Lidiane G. Felippe, ${ }^{a}$ Fernando Cotinguiba, ${ }^{b}$ Massuo J. Kato ${ }^{c}$ and \\ Maysa Furlan*,a \\ aInstituto de Química, Universidade Estadual Paulista (Unesp), \\ CP 355, 14800-900 Araraquara-SP, Brazil \\ ${ }^{b}$ Instituto de Pesquisas de Produtos Naturais (IPPN), Universidade Federal do Rio de Janeiro (UFRJ), \\ 21941-902 Rio de Janeiro-RJ, Brazil \\ 'Instituto de Química, Universidade de São Paulo, 05508-000 São Paulo-SP, Brazil

\begin{abstract}
The known kavalactones $(E)$-4-methoxy-6-styryl-2H-pyran-2-one, 4-methoxy-
\end{abstract} \\ 6-(3-phenyloxiran-2-yl)-2H-pyran-2-one, 6-(1,2-dihydroxy-2-phenylethyl)-4-methoxy-2H-pyran- \\ 2-one, the three benzoic acid derivatives methyl-4-methoxy-3-(3'-methyl-2'-butenyl)benzoate and \\ methyl 2,2-dimethyl-4-oxochroman-6-carboxylate, and a new methyl 4-methoxy-3-(3-methylbut- \\ 2-enoyl)benzoate were isolated from the ethanolic extract of Piper fuligineum. The structures of \\ these compounds were determined by using a combination of spectroscopic methods, including \\ 1D- and 2D-nuclear magnetic resonance spectroscopy and high-resolution mass spectrometry. This \\ is the first report of the chemical study of $P$. fuligineum, and the methyl 4-methoxy-3-(3-methylbut- \\ 2-enoyl)benzoate is described as a new natural product.
}

Keywords: Piper fuligineum, Piperaceae, kavalactones, benzoic acid derivatives

\section{Introduction}

Studies of Piper species have revealed the presence of several classes of secondary metabolites, ${ }^{1}$ including alkaloids, amides, ${ }^{2-6}$ chromenes, ${ }^{7,8}$ neolignans, ${ }^{9}$ lignans, terpenes, ${ }^{10,11}$ benzoic acid derivatives ${ }^{12,13}$ and kavalactones. ${ }^{14}$ Many of these compounds have shown important biological activities, including antifungal, ${ }^{4}$ anti-inflammatory, ${ }^{15}$ antiparasitic, ${ }^{13}$ antioxidant, ${ }^{16}$ anticoagulant ${ }^{17}$ and trypanocidal properties. ${ }^{18-20}$ The rhizome of Piper methysticum, known as "kava-kava" in Hawaii and the South Pacific Islands, is used to prepare a beverage to treat anxiety. ${ }^{21,22}$ The major compounds isolated from this species are the kavalactones kavain and methysticin. Although it has been banned in the UK and several other countries due to its potential hepatotoxicity, the mechanism for this hepatotoxicity is still unclear. ${ }^{23} \mathrm{To}$ date, the occurrence of this class of compounds is limited to a few Piper species, including $P$. rusbyi, ${ }^{24}$ P. sanctum,${ }^{25}$ P. cubeb $^{26}$ and P. dilatatum. ${ }^{14}$

*e-mail: maysaf@iq.unesp.br
Piper fuligineum Kunth is a shrub endemic to Brazil that grows mainly in Cerrado, Caatinga and Atlantic Forest. ${ }^{27-30}$ This species was previously found to contain the kavalactone demethoxy-yagonin $((E)$-4-methoxy6-styryl-2H-pyran-2-one (1)), which showed inhibitory activity towards hepatitis $\mathrm{C}$ virus replication. ${ }^{31}$ In addition to $\mathbf{1}$, we also report the isolation of two kavalactones from P. fuligineum leaves, 4-methoxy-6-(3-phenyloxiran-2-yl)$2 H$-pyran-2-one (2) and 6-(1,2-dihydroxy-2-phenylethyl)4-methoxy-2H-pyran-2-one (3), as well as three benzoic acid derivatives, methyl-4-methoxy-3-(3'-methyl-2'-butenyl) benzoate (4), methyl 2,2-dimethyl-4-oxochroman6-carboxylate (5), and methyl 4-methoxy-3-(3-methylbut2-enoyl)benzoate (6). Compounds 1-5 were previously isolated from Piper species, but compound $\mathbf{6}$ is, to the best of our knowledge, a new natural product.

\section{Experimental}

General

One-dimensional $\left({ }^{1} \mathrm{H},{ }^{13} \mathrm{C}\right)$ and two-dimensional (gHMBC (gradient heteronuclear multiple bond correlation) 
and gHMQC (gradient heteronuclear multiple quantum correlation)) spectra were recorded on a Varian Inova-500 $(11.7 \mathrm{~T})$ spectrometer at $500 \mathrm{MHz}\left({ }^{1} \mathrm{H}\right)$ and $125 \mathrm{MHz}$ $\left({ }^{13} \mathrm{C}\right)$ using $\mathrm{CDCl}_{3}$ as a solvent and TMS as a reference. HR-ESI-MS (high-resolution electrospray ionization mass spectrometry) was measured using a Bruker Daltonics model ultrOTOF $F_{Q}$ ESI-TOF (time of flight) instrument. Separations by column chromatography (CC) were carried out using silica gel (230-400 mesh; Merck). All solvents were distilled prior to use. High-performance liquid chromatography (HPLC) separations were performed on a Varian PrepStar model SD-1 LC/UV/VIS chromatograph equipped with a Phenomenex C-18 reversed phase column $(250 \times 21.2 \mathrm{~mm})$.

Plant material

The leaves of P. fuligineum Kunth were collected at the Chácara Flora (Araraquara-SP, Brazil) in October of 2006 and identified by Dr Inês Cordeiro. A voucher specimen (Kato-0720) has been deposited at the Herbarium of the Instituto de Botânica of Universidade de São Paulo (São Paulo-SP, Brazil).

Isolation of compounds

Dried leaves $(420 \mathrm{~g})$ of $P$. fuligineum were milled, extracted with $\mathrm{EtOH}$, and it was concentrated under vacuum to yield $54.4 \mathrm{~g}$ of the extract. The extract was resuspended in $\mathrm{MeOH}: \mathrm{H}_{2} \mathrm{O}$ (4:1) and partitioned with hexane, $\mathrm{CHCl}_{3}$ and EtOAc sequentially. The portion soluble in $\mathrm{CHCl}_{3}$ $(13.0 \mathrm{~g})$ was subjected to $\mathrm{CC}$ over silica gel and eluted with a gradient of hexanes-EtOAc to yield fractions 1-23. Fraction 5 (2.15 g) was submitted to flash CC over silica gel eluted with a gradient of hexanes-EtOAc yielding sub-fractions 5-1 to 5-28. Sub-fraction 5-1 (320.3 mg) was submitted to preparative HPLC eluted with $\mathrm{MeOH}: \mathrm{H}_{2} \mathrm{O}$ (1:1) to afford the compounds $\mathbf{6}(4.6 \mathrm{mg}), \mathbf{4}(7.4 \mathrm{mg})$ and $5(5.8 \mathrm{mg})$. Fraction $8(2.0 \mathrm{~g})$ was subjected to CC over silica gel and eluted with a gradient of $n$-hexanes-EtOAc providing fractions 8-1 to 8-16. Sub-fraction 8-4 afforded $\mathbf{1}(58.8 \mathrm{mg})$. Fraction $16(1.3 \mathrm{~g})$ was subjected to preparative HPLC and eluted with isocratic $\mathrm{MeOH}: \mathrm{H}_{2} \mathrm{O}$ (65:35) to afford $\mathbf{3}(2.3 \mathrm{mg})$.

Methyl 4-methoxy-3-(3-methylbut-2-enoyl)benzoate (6)

Amorphous white powder, UV (MeOH) $\lambda_{\max } / \mathrm{nm} 253$, $305 ;{ }^{1} \mathrm{H}$ and ${ }^{13} \mathrm{C}$ nuclear magnetic resonance (NMR), see Table 1. HRMS/ESI-TOF $m / z$ (rel. int.): $249.1129[\mathrm{M}+\mathrm{H}]^{+}$ (80) (calcd. for $\left.\mathrm{C}_{14} \mathrm{H}_{17} \mathrm{O}_{4}, 249.1126\right) ; 271.0949[\mathrm{M}+\mathrm{Na}]^{+}$ (98) (calcd. for $\mathrm{C}_{14} \mathrm{H}_{16} \mathrm{O}_{4} \mathrm{Na}, 271.0946$ ).
Table 1. ${ }^{1} \mathrm{H}$ and ${ }^{13} \mathrm{C}$ NMR spectroscopic data for compound 6 (500 MHz, $\mathrm{CDCl}_{3}, \delta$ in ppm, $J$ in $\mathrm{Hz}$ ), isolated from P. fuligineum

\begin{tabular}{|c|c|c|c|}
\hline Position & $\delta_{\mathrm{C}}$ & $\delta_{\mathrm{H}}($ mult; $J$ in $\mathrm{Hz})$ & gHMBC \\
\hline 1 & 130.9 & - & \\
\hline 2 & 131.7 & $8.14(\mathrm{~d} ; 2.5 ; 1 \mathrm{H})$ & $\mathrm{C} 1$ ", $\mathrm{C} 1$ ' \\
\hline 3 & 122.6 & - & \\
\hline 4 & 161.0 & - & \\
\hline 5 & 111.2 & $6.91(\mathrm{~d} ; 8.5 ; 1 \mathrm{H})$ & \\
\hline 6 & 133.9 & $8.03(\mathrm{dd} ; 8.5$ and $2.5 ; 1 \mathrm{H})$ & $\mathrm{C} 1 ", \mathrm{C} 4$ \\
\hline 7 & 55.9 & $3.87(\mathrm{~s} ; 3 \mathrm{H})$ & $\mathrm{C} 4$ \\
\hline 1 ' & 191.9 & - & \\
\hline $2^{\prime}$ & 124.8 & $6.49(\mathrm{~m} ; 1 \mathrm{H})$ & $\mathrm{C} 1^{\prime}, \mathrm{C} 5^{\prime}$ \\
\hline 3 ' & 156.5 & - & \\
\hline $4^{\prime}$ & 21.3 & $2.16(\mathrm{~d} ; 1.0 ; 3 \mathrm{H})$ & $\mathrm{C} 1^{\prime}, \mathrm{C} 2^{\prime}, \mathrm{C} 3^{\prime}, \mathrm{C} 5^{\prime}$ \\
\hline 5 , & 28.0 & $1.90(\mathrm{~d} ; 1.0 ; 3 \mathrm{H})$ & $\mathrm{C} 2^{\prime}, \mathrm{C} 3^{\prime}$ \\
\hline $1 "$ & 166.3 & - & \\
\hline $2 "$ & 52.0 & $3.82(\mathrm{~s} ; 3 \mathrm{H})$ & $\mathrm{C} 1 ”$ \\
\hline
\end{tabular}

\section{Results and Discussion}

The EtOH extract from the leaves of $P$. fuligineum was suspended in $\mathrm{MeOH}: \mathrm{H}_{2} \mathrm{O}$ (4:1) and sequentially partitioned against the hexanes, $\mathrm{CHCl}_{3}$ and EtOAc. ${ }^{1} \mathrm{H} \mathrm{NMR}$ analysis of the concentrated fractions revealed signals of aromatic compounds $(\delta 6-8)$ in the $\mathrm{CHCl}_{3}$ fraction and more signals than in hexanes or EtOAc. Thus, the $\mathrm{CHCl}_{3}$ soluble fraction was submitted to a chromatographic purification procedure, which yielded three kavalactones (1-3) and three benzoic acid derivatives (4-6).

The known compounds were identified as (E)-4-methoxy-6-styryl-2H-pyran-2-one (1), ${ }^{25,26,31}$ 4-methoxy-6-(3-phenyloxiran-2-yl)-2H-pyran-2-one (2), 6-(1,2-dihydroxy-2-phenylethyl)-4-methoxy- $2 H$-pyran2-one (3), ${ }^{24}$ methyl-4-methoxy-3-(3'-methyl-2'-butenyl) benzoate (4) ${ }^{32,33}$ and methyl 2,2-dimethyl-4-oxochroman6-carboxylate (5) by NMR and/or by HRMS (Supplementary Information) as well as by comparison with the literature data. ${ }^{13,14,24,34,35}$

The molecular formula of $\mathbf{6}$ was established as $\mathrm{C}_{14} \mathrm{H}_{16} \mathrm{O}_{4}$ by HRMS $\left([\mathrm{M}+\mathrm{H}]^{+}\right.$observed $m / z$ 249.1129, calcd. 249.1126; $[\mathrm{M}+\mathrm{Na}]^{+}$observed $\mathrm{m} / z$ 271.0949, calcd. 271.0946), which matched the overall ${ }^{1} \mathrm{H}$ and ${ }^{13} \mathrm{C}$ NMR analysis. The ${ }^{1} \mathrm{H}$ NMR spectrum (Table 1) exhibited resonances indicative of one meta-coupled aromatic hydrogen at $\delta 8.14(\mathrm{H}-2, \mathrm{~d}, J 2.5 \mathrm{~Hz}, 1 \mathrm{H})$, one ortho-coupled at $\delta 6.91(\mathrm{H}-5, \mathrm{~d}, J 8.5 \mathrm{~Hz}, 1 \mathrm{H})$, and one ortho-meta-coupled at $\delta 8.03$ (H-6, dd, $J 8.5$ and $2.5 \mathrm{~Hz}$, $1 \mathrm{H})$. Doublets at $\delta 1.90\left(\mathrm{H}^{-} 5^{\prime}, \mathrm{d}, J 1.0 \mathrm{~Hz}, 3 \mathrm{H}\right)$ and 2.16 $\left(\mathrm{H}_{-}{ }^{\prime}, \mathrm{d}, J 1.0 \mathrm{~Hz}, 3 \mathrm{H}\right)$ and a multiplet at $\delta 6.49\left(\mathrm{H}-2^{\prime}\right.$, 
$\mathrm{m}, 1 \mathrm{H})$ were assigned to the oxidized prenyl group. The singlets observed at $\delta 3.82(\mathrm{H}-2 ", \mathrm{~s}, 3 \mathrm{H})$ and 3.87 (H-7, $\mathrm{s}, 3 \mathrm{H})$ corresponded to the methyl ester and aromatic methoxyl groups, respectively. The oxidized prenyl group was confirmed by the gHMBC and gHMQC cross-peaks of $\delta 1.90\left(\mathrm{H}-5^{\prime}\right)$ and $2.16\left(\mathrm{H}-4^{\prime}\right)$ to $\mathrm{C}-2^{\prime}(\delta$ 124.8). In addition, cross-peaks of both $\mathrm{H}-6(\delta 8.03)$ and $\mathrm{H}-2(\delta 8.14)$ to C-1" $(\delta 166.3)$ were observed, thus confirming the ester substituent at the $\mathrm{C}-1$ position of the aromatic ring. The cross-peak of H-7 $(\delta 3.87)$ to C-4 $(\delta$ 161.0) corroborated the placement of the methoxy group. The ${ }^{13} \mathrm{C}$ NMR data corroborated the substituents of aromatic ring, and all signals were assigned accordingly based on the gHMBC data (Table 1). Thus, compound 6 was established as methyl 4-methoxy-3-(3-methylbut-2-enoyl)benzoate, a methylated derivative of methyl taboganate. ${ }^{36}$

The biogenesis involved in the formation of kavalactones and benzoic acid derivatives in $P$. fuligineum suggests that shikimic acid is the key building block in their formation (Figure 1). Additionally, the oxidation level of the benzoic acid derivatives in P. fuligineum indicates that such oxidations are important processes for achieving the chemical diversity observed for the kavalactones and benzoic acid derivatives, which includes a chromanone. The biosynthetic pathways

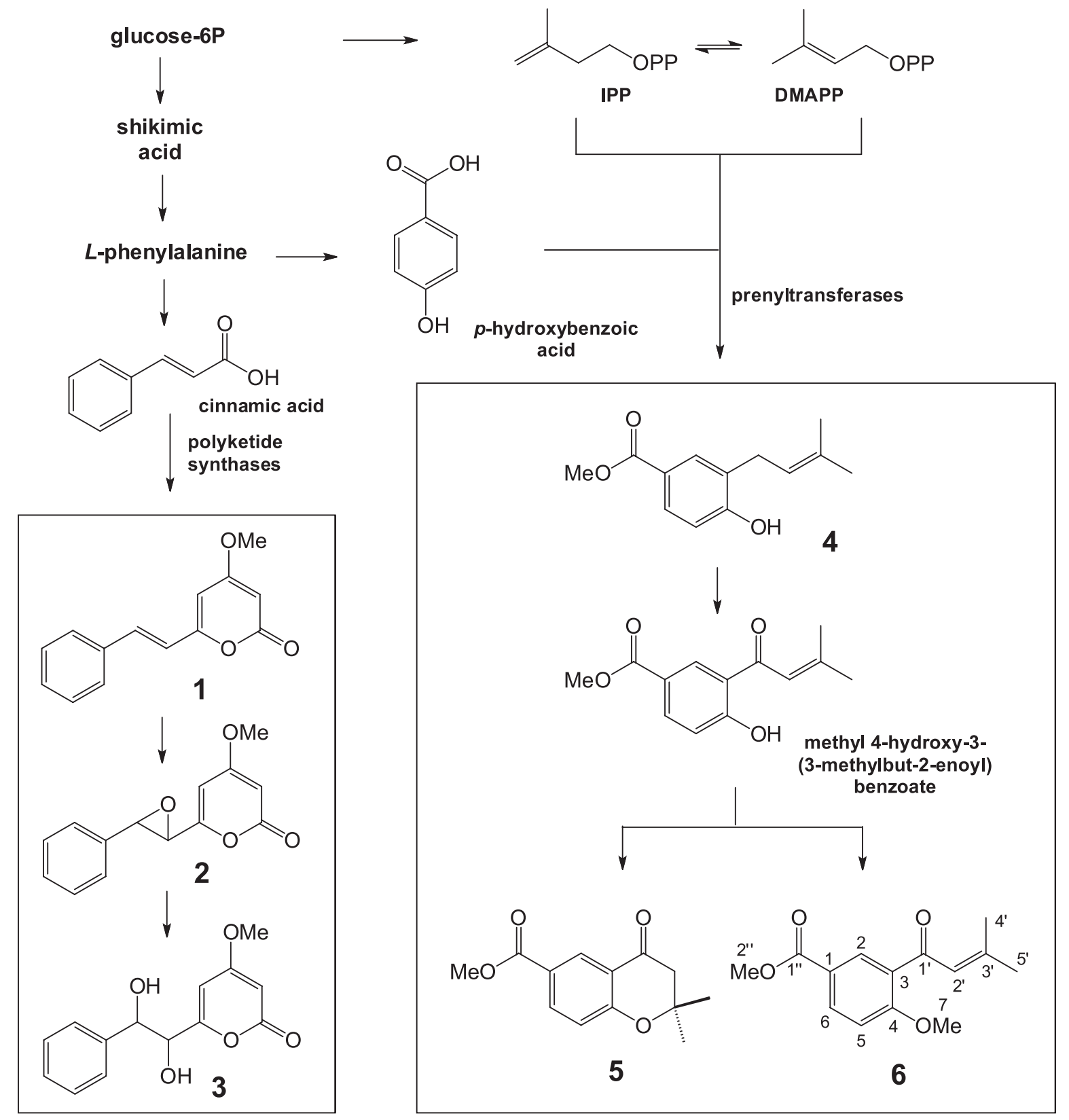

Figure 1. Compounds isolated from P. fuligineum (1-6) and their biosynthetic relationships. IPP: isopentenyl diphosphate; DMAPP: 3,3-dimethylallyl diphosphate. 
in Piper fuligineum suggest that this species is an important target whose capacity to produce kavalactones similar to other Piper species should be explored and that can be used to discover new pharmacological applications.

\section{Conclusions}

In this work, we describe the identification and structural elucidation of six compounds from the leaves of $P$. fuligineum, including one new prenylated benzoic acid derivative in addition to kavalactones, which represent an important class of compounds, but occur in only a few specific plant species. The characterization of these compounds expands our knowledge on the chemical diversity of Piper species.

\section{Supplementary Information}

Supplementary information is available free of charge at http://jbcs.org.br as PDF file.

\section{Acknowledgments}

This work was supported by grants from the State of São Paulo Research Foundation (FAPESP): Research, Innovation and Dissemination Centers (CEPID, CIBFar-2013/07600-3) as well as 05/51850-9 and 14/50316-7. M. F. and M. J. K. are grateful to $\mathrm{CNPq}$ for research fellowships. B. F. M., L. G. F. and F. C. thank FAPESP for the provision of scholarship and fellowship, respectively (2011/16752-6, 2013/15306-8 and 2007/56140-4).

\section{References}

1. Kato, M. J.; Furlan, M.; Pure Appl. Chem. 2007, 79, 529.

2. Alécio, A. C.; Bolzani, V. S.; Young, M. C.; Kato, M. J.; Furlan, M.; J. Nat. Prod. 1998, 61, 637.

3. Navickiene, H. M. D.; Alecio, A. C.; Kato, M. J.; Bolzani, V. S.; Young, M. C. M.; Cavalheiro, A. J.; Furlan, M.; Phytochemistry 2000, 55, 621 .

4. Silva, R. V.; Navickiene, H. M. D.; Kato, M. J.; Bolzani, V. S.; Méda, C. I.; Young, M. C. M.; Furlan, M.; Phytochemistry 2002, 59, 521 .

5. Cotinguiba, F.; López, S. N.; Labate, C. A.; Debonsi, H. M.; Kato, M. J.; Furlan, M.; Planta Med. 2012, 78, 1070.

6. Bao, N.; Ochir, S.; Sun, Z.; Borjihan, G.; Yamagishi, T.; J. Nat. Med. 2014, 68, 211.

7. Baldoqui, D. C.; Kato, M. J.; Cavalheiro, A. J.; Bolzani, V. S.; Young, M. C. M.; Furlan, M.; Phytochemistry 1999, 51, 899.

8. Lago, J. H. G.; Young, M. C. M.; Reigada, J. B.; Soares, M. G.; Roesler, B. P.; Kato, M. J.; Quim. Nova 2007, 30, 1222.
9. Chen, S.; Huang, H. Y.; Cheng, M. J.; Wu, C. C.; Ishikawa, T.; Peng, C. F.; Chang, H. S.; Wang, C. J.; Wong, S. L.; Chen, I. S.; Phytochemistry 2013, 93, 203.

10. Martins, R. C.; Latorre, L. R.; Sartorelli, P.; Kato, M. J.; Phytochemistry 2000, 55, 843.

11. Baldoqui, D. C.; Bolzani, V. S.; Furlan, M.; Kato, M. J.; Marques, M. O. M.; Quim. Nova 2009, 32, 1107.

12. Lago, J. H.; Ramos, C. S.; Casanova, D. C.; Morandim, A. A.; Bergamo, D. C.; Cavalheiro, A. J.; Bolzani, V. S.; Furlan, M.; Guimarães, E. F.; Young, M. C.; Kato, M. J.; J. Nat. Prod. 2004, 67, 1783.

13. Flores, N.; Jiménez, I. A.; Giménez, A.; Ruiz, G.; Gutiérrez, D.; Bourdy, G.; Bazzocchi, I. L.; J. Nat. Prod. 2008, 71, 1538.

14. dos Santos, R. A.; Ramos, C. S.; Young, M. C. M.; Pinheiro, T. G.; Amorim, A. M.; Kato, M. J.; Batista, R.; J. Chem. 2013, article ID 160165, DOI 10.1155/2013/160165.

15. Lin, L. C.; Shen, C. C.; Shen, Y. C.; Tsai, T. H.; J. Nat. Prod. 2006, 69, 842 .

16. Swapna, N. L.; Ammani, K.; Saripalli, H. K. R. P.; Free Radicals Antioxid. 2012, 2, 68.

17. Wonhwa, L.; Hayoung, Y.; Sae-Kwang, K.; Ah, K. J.; Jong-Sup, B.; BMB Rep. 2013, 46, 484.

18. Batista Junior, J. M.; Lopes, A. A.; Ambrósio, D. L.; Regasini, L. O.; Kato, M.; Bolzani, V. S.; Cicarelli, R. M.; Furlan, M.; Biol. Pharm. Bull. 2008, 31, 538.

19. Regasini, L. O.; Cotinguiba, F.; Passerini, G. D.; Bolzani, V. S.; Cicarelli, R. M. B.; Kato, M. J.; Furlan, M.; Rev. Bras. Farmacogn. 2009, 19, 199.

20. Cotinguiba, F.; Regasini, L. O.; Bolzani, V. S.; Debonsi, H. M.; Passerini, G. D.; Cicarelli, R. M. B.; Kato, M. J.; Furlan, M.; Med. Chem. Res. 2009, 18, 703.

21. Dharmaratne, H. R. W.; Nanayakkara, N. P. D.; Khana, I. A.; Phytochemistry 2002, 59, 429.

22. Tabudravu, J. N.; Jaspars, M.; South Pac. J. Nat. Sci. 2005, 23, 26.

23. Ernst, E.; Br. J. Clin. Pharmacol. 2007, 64, 415.

24. Flores, N.; Cabrera, G.; Jiménez, I. A.; Piñero, J.; Giménez, A.; Bourdy, G.; Cortés-Selva, F.; Bazzocchi, I. L.; Planta Med. 2007, 73, 206.

25. Mata, R.; Morales, I.; Pérez, O.; Rivero-Cruz, I.; Acevedo, L.; Enriquez-Mendoza, I.; Bye, R.; Franzblau, S.; Timmermann, B.; J. Nat. Prod. 2004, 67, 1961.

26. Aboul-Enein, Y. H.; Kładnac, A.; Krukd, I.; J. Lumin. 2011, 26, 202.

27. Kotchetkoff-Henriques, O.; Joly, C. A.; Bernacci, L. C.; Rev. Bras. Bot. 2005, 28, 541.

28. Felfili, J. M.; Silva-Junior, M. C.; Mendonça, R. C.; Fagg, C. W.; Filgueiras, T. S.; Mecenas, V.; Heringeriana 2007, 1, 25.

29. Guimarães, E. F.; Medeiros, E. S. In Plantas da Floresta Atlântica; Stehmann, J. R.; Forzza, R. C.; Salino, A.; Sobral, M.; da Costa, D. P.; Kamino, L. H. Y., eds.; Jardim Botânico do Rio de Janeiro: Rio de Janeiro, Brazil, 2009, p. 411. 
30. Oliveira, G. C.; Araújo, G. M.; Barbosa, A. A. A.; Rodriguesia 2009, 60, 1077.

31. Jardim, A. C. G.; Igloi, Z.; Shimizu, J. F.; Santos, V. A. F. F. M.; Felippe, L. G.; Mazzeu, B. F.; Amako, Y.; Furlan, M.; Harris, M.; Rahal, P.; Antiviral Res. 2015, 115, 39.

32. Roussis, V.; Ampofo, S. A.; Wiemer, D. F.; Phytochemistry 1990, 29, 1787.

33. Terreaux, C.; Gupta, M. P.; Hostettmann, K.; Phytochemistry 1998, 38, 350.

34. Miranda, R. P.; Bernard, C. B.; Durst, T.; Arnason, J. T.; Vindas, P. S.; Poveda, L.; Román, L. S.; J. Nat. Prod. 1996, 60, 282.
35. Oliveira, L. C. P.; Mause, R.; Nunomura, S. M.; J. Braz. Chem. Soc. 2005, 16, 1439.

36. Carbonnelle, D.; Jacquot, C.; Lanco, X.; Le Dez, G.; Tomasoni, C.; Briand, G.; Tsotinis, A.; Calogeropoulou, T.; Roussakis, C.; Int. J. Cancer 2001, 92, 388.

Submitted: June 30, 2017

Published online: December 6, 2017 